\title{
Do Middle School Science Textbook Enclose an Entity of Science Literacy?
}

\author{
Didit Ardianto $^{*}$, Indarini Dwi Pursitasari ${ }^{*}$ \\ ${ }^{*}$ University of Pakuan, Bogor, Indonesia \\ Corresponding Author: didit.ardianto@unpak.ac.id
}

\begin{abstract}
This study aims to analyze the middle school of science the textbook based on science literacy. We used descriptive analysis to explore the domain of science literacy at 3 middle science textbooks. Observation Sheet that contain the domain of science literacy (adopted from Chiappetta, Fillman \& Sethna) is used to capture the present category of science literacy (body of knowledge, way of investigating, way of thinking, and interaction of science, technology and society) in any textbook. The results showed that middle school science textbooks have not yet provide a balance between body of knowledge, way of Investigating, way of thinking, and interaction of science, technology and society. The Middle science textbooks still dominate with science as a way of knowledge. Middle School science textbook that used to support science teaching should be provide balance on all four aspects of science literacy. Therefore, The development that focusing on middle school science textbooks based on science literacy need to be implemented.
\end{abstract}

Keywords: Science Literacy, Teaching Materials

\section{INTRODUCTION}

Science literacy is a competency which is the goal of learning science. science literacy of students who have student understanding of the nature of science and scientific reasoning(scientificreasoning) students (Lawson, 2009, in Piraksaa, Srisawasdib, \& Koulc, 2014). Science literacy is important to be mastered by students in relation to how the student can understand the environmental, health, economic and other problems faced by modern society that relies heavily on technology and progress and development of science (Joseph, 2003).

Development of student' science literacy have been carried out by practitioners of science education. Ardianto \& Rubini (2016) examines the science literacy development capabilities through the implementation of inquiry-based learning. The Results show that inquiry-based learning can improve student' science literacy but in the medium category. Brickman et al. (2009), Alfiery et al. (2010) and Nbina (2103) also states that constructivism-based science learning (inquiry, discovery, PBL) can increase the student' science literacy in the medium category. Based on these results it can be concluded that the development of student' science literacy not enough just to inquirybased learning process. However, the need for textbooks to support teachers in the learning.

Textbooks can be regarded as special in the learning process as a supplements. Weiss, et.al (Lumpe $\&$ Beck, 1996) states that $90 \%$ of advanced science teachers use textbooks during the learning process. Blystone estimates that $75 \%$ of the textbook used for teaching in the classroom and $90 \%$ for homework. This relates to the previous studies showing that textbooks used by $90 \%$ of all science teachers and $90 \%$ of the allocation of instructional time. The selection of appropriate textbooks is expected an increase understanding of science that could ultimately improve the student' science literacy (Lumpe \& Beck, 1996)

Based on the explanation above, we need a way analysis of books involving aspects containing the science literacy, its content, process and context. The purpose of this study to examine textbooks charged affection scientific literacy. Furthermore, the following research questions: "How is the scope of science literacy in the textbook used in schools in terms of knowledge of science (body of knowledge), the investigation of the nature of science (way of investigating), science as a way of thinking (way of thinking) and Interaction science, technology and society (Interaction of science, technology, andsociety)?

\section{RESEARCH METHODS}

This study use descriptive analysis. The Population in this study is middle sschool science textbook. The sample in this study were a few pages in the book are analyzed, taken in a random way. Observation Sheet used to capture presesent of science literacy indicators on te books (adopted from Chiappetta, Fillman \& Sethna (1993) in the journal entitled Do Middle school Life Science Textbooks Provide a balance of Science literacy Themes). The procedure of this study include: 
a. Phase elections textbooks

Textbooks are selected based on the following criteria: Textbooks have passed Book Center (Pusbuk); Textbooks most widely used by middle school students; Choosing 3 middle school science textbook from different publishers which widely used by students (Textbook A, Textbook B, and Textbook C).

b. Phase of sampling

Samples were taken using multistage sampling (sampling some stage). This study use two stage sampling. According to Cochran (1991) The first phase of selecting a sample from the main units and the second phase of selecting a sample of units of the second phase / subunit of each main unit selected.

1) Stage 1: Selection Chapter

Chapter analyzed taken as many as $20 \%$ of the total number of existing chapter in each book analyzed. Chapter analyzed taken at random from the total number of chapters that exist in each book analyzed. It is adapted from the Journal of research in science teaching (Chiappetta, Fillman \& Sethna, 1993).

2) Stage 2: Selection

Pages analyzed taken as many as $20 \%$ of the total number of pages within each chapter are analyzed. Maps were analyzed taken at random from the total number of pages within each chapter are analyzed. A list of text elements (units being analyzed) are passages, questions, images, tables and description, brief comments are complete, and the activity of the laboratory or Hands-on activities. A list of pages that do not need to be analyzed in the textbook as the page that contains only review questions and vocabulary, and the inclusion of goals and objectives (Chiappetta, Fillman \& Sethna, 1991a). Paragraph incomplete analyzed from the beginning of the paragraph, either before or after viewing the page.

c. Data collection phase

1) Each paragraph on the page is analyzed and matched with existing indicators of science literacy.

2) Calculating the present of science literacy in each paragraph are analyzed and write it in the tally.

\section{RESULTS AND DISCUSSION}

The results showed that the middle science textbooks being used do not meet the criteria of science literacy. The present of component science literacy on textbook can be seen in Figure 1.1 The Percentage of indicator science literacy on the book A that appears is the category of science as a body of knowledge by $78,1 \%$. The category of science as a way to investigate is $41.66 \%$. The category of science as a way of thinking is $33.33 \%$. For the category of science as the interaction between science, technology, and society amounted to $31.25 \%$. The present of indicators of science literacy in the textbook B which is the category of science as a body of knowledge amounted to $71.87 \%$. The category of science as a way to investigate is $62.5 \%$. The category of science as a way of thinking is $55.55 \%$. For the category of science as the interaction between science, technology, and society of $37.5 \%$. While the results of the percentage of indicators of science literacy in the textbook $\mathrm{C}$ is the category of science as a body of knowledge amounted to $78.1 \%$. The category of science as a way to investigate is $45.8 \%$. Category of science as a way of thinking is $44.44 \%$. For the category of science as the interaction between science, technology, and society of $37.5 \%$

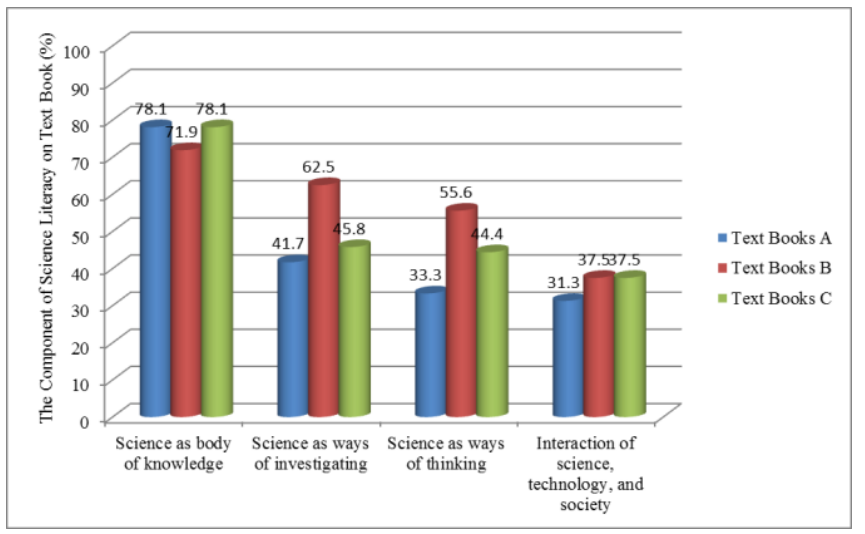

Figure 1.1 The Present of Science Literacy on Textbooks

The study showed that almost all the books that were analyzed have not loaded proportionally literacy aspect. The percentage of science literacy' domain each book indicates that the material at all the books emphasize the category of science as a body of knowledge. Although there is one book that has a percentage above $50 \%$ in the category of science as a way to investigate and category of science as a way of thinking but category of science as a body of knowledge on the textbooks were dominnat. The average percentage of science literacy indicators for each book are shown in Figure 1.2.

Figure 1.2 showed that the category of science literacy in each book indicates different percentages. The average percentage of science literacy indicator of $\mathrm{A}, \mathrm{B}$, and $\mathrm{C}$ are the most emerging is the category of science as a body of knowledge amounted to $76.02 \%$. The category of science as a way to investigate is $49.98 \%$. The category of science as a way of thinking is $44.44 \%$. For the category of science as the interaction between science, technology, and society amounted to $35.42 \%$. 


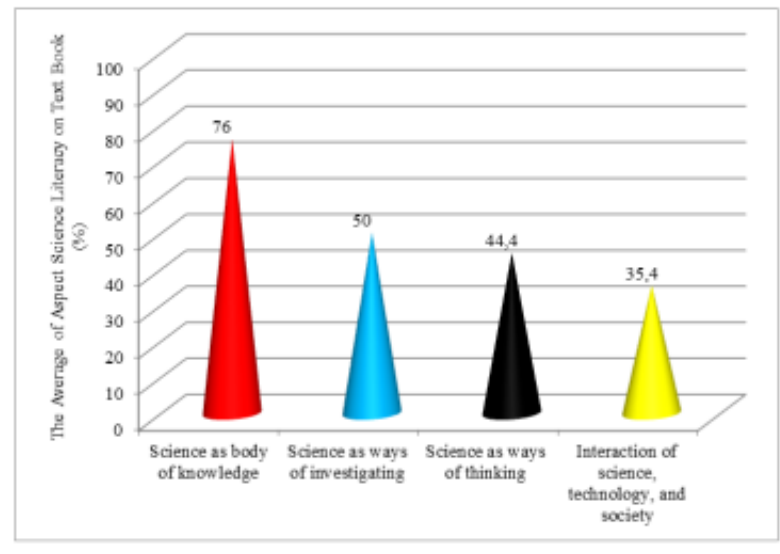

Figure 4.2 The average percentage of category science literacy for every book

These results indicate that the material in all the book emphasizes the category of scientific knowledge such as facts, concepts, principles, laws, hypotheses, theories, models, and ask students to recall knowledge or information. This is consistent with research Chiappetta, et.al (1993), that the life science textbooks and chemistry in high school more focused on collection of knowledge of science are on the subject matter with a lot of presents definitions and describes the process of life

Using textbooks in learning should be able to make the students understand the material being studied. Its should be made the students do not get bored while studying. But many textbooks used are still far from the expected, such as interviews from several teachers in secondary schools in the state that the textbook which has been used particularly middle school science textbooks is still far from the expected, it emphasizes on concepts and theory. Based on this research science textbooks, giving the material more concerned with categories of knowledge alone. Students are just good at memorization, but less skilled in applying their knowledge, it may be related to a tendency to use memorization as a vehicle for mastering science, not the ability to think Adisendjaja (2009). Supposedly students should be able to investigate new things, not just memorize science. Its realized that the way students learn science can affect the level of scientific literacy. Learning that just poured concept alone would not provide experience for students and make students' science literacy is low. The presence of learning support materials in order to increase students' science literacy skills certainly come into play. One of the materials in question is the student's textbook.

The results of the analysis of science literacy in each category shows the percentage of different books, almost all books were analyzed yet included in a balanced literacy aspect. The average percentage of present category science literacy just focus on science as a body of knowledge amounted to $76.02 \%$. The category of science as a way to investigate is $49.98 \%$. The category of science as a way of thinking is $44.44 \%$. For the category of science as the interaction between science, technology, and society amounted to $35.42 \%$. Literacy aspects contained in the book most aspects of knowledge, while aspects of the investigation, a way of thinking and the relationship of science to technology and society are categorized minimal. In fact there were only $31.25 \%$ book contains science literacyaspects of relevance to technology and society.

Rutherford \& Ahlgen, as quoted by Lumpe \& Beck (1996), suggests that students should understand the nature of scientific investigation, including the processes of science when performing activities of direct high-level cognitive. Skills processes that have been successfully developed, will ultimately help students to form a scientific attitude and thought processes. Thus, according Lumpe \& Beck (1996), states that the textbook is not only load content only chemical but also to provide opportunities for students to investigate themselves, understand the important role of chemistry, and describes how that is done by scientists in developing an understanding of certain subjects. The low category of science literacy as a way of thinking on the above studies due to science textbooks studied not emphasize how a scientist conducting experiments, showing the development of science, causality, discusses the facts and evidence, and presents scientific methods and problem solving (Chieppetta et al. , 1991).

Science textbooks do not integrate 4 sets of one another that can show the nature of science as a whole, and the content of science is separated from the nature of science used by scientists to develop ideas and theories. The text section should not only contain Biological content but should also provide students with the opportunity to investigate on their own, understand the important role of Biology in our society, and describe the way scientists do in their affairs in developing an understanding of a particular lesson. Biology textbooks should incorporate all aspects related to science, including the investigation of the nature of science, the interaction of science, technology and society, and Science as a way of recognizing the text itself directly and not in a separate section (Chiapetta, Fillman and Sethna, 1991a, 1991b) .

The middle science textbooks should focus on the theme of the Inquiry on the nature of science embodied in the science process skills. Science process skill need to be developed through hands-on experience as a learning experience and be realized when the activities are in progress. Process skills involve cognitive or intellectual, manual and social skills so that science learning will be more meaningful. Thus, learning with a process skill approach allows students 
to study and even find concepts that become meaningful.

\section{CONCLUSION}

The presentation of the analyzed book has not fully refers to the science literacy indicator, although all the analyzed books present the category of science literacy as a way of thinking, but the proportion is still far below the category of science knowledge. Whereas to achieve the goal of science education there should be a textbook of science, especially science textbooks that contain four categories of science literacy are balanced. Teachers that can support learning, which not only emphasize science knowledge alone, but must include the category of science literacy in a balanced way. Science lessons should be more emphasis on student activity, lessen activities to remember knowledge of facts, more emphasis on the process of science skills to get the concept, students learn actively and most of the time the students spent in the laboratory or work field.

\section{REFERENCES}

Adisendjaja, Y.H. 2009. Analisis Buku Ajar Biologi SMA Kelas X di Kota Bandung Berdasarkan Literasi Sains. Makalah. Pendidikan Biologi UPI: tidak diterbikan

Alfieri, L., Brooks, P.J. \& Aldrich, J.N. 2010. Does Discovery-Based Instruction Enhance Learning?. Journal of educational Psycology. (103)1:1-18.

Ardianto, D dan Rubini, B. 2016. Komparasi Literasi Sains Siswa Pada Pembelajaran IPA Terpadu dengan Model Guided Discovery dan Problem Based Learning. Jurnal Pendidikan IPA Indonesia.

Brickman, P., Gormally, C., Armstrong N dan Hallar, B. 2009. Effects of Inquiry-Based Learning on Students'science Literacy Skills dnd Confidence. International Journal for the Scholarship of Teaching and Learning, 3(2).

Chiappetta, E.L, Fillman, D.A, dan Sethna, G.H.1991. "A Method to Quantify Major Themes of Scientific Literacy in Science Textbooks". Journal of research in science teaching, 28(8), 713-725.

Chiappetta, E.L, Fillman, D.A, dan Sethna, G.H. 1991. "A Quantitative Analysis of High School Chemistry Textbooks for Scientific Literacy Themes and Expository Learning Aids". Journal of research in science teaching, 28(10), 939-951.

Chiappetta, E.L, Fillman, D.A, dan Sethna, G.H. 1993. "Do Middle School Life Science Textbooks Provide a Balance of Scientific Literacy Themes?". Journal of research in science teaching, 30(2), $787-797$

Cochran, W.G. 1991. Teknik Penarikan Sampel Edisi ketiga. Jakarta: Universitas Indonesia (UI-Press).

Leonard, W.H dan Penick, J. E. 1993. "What's Important in Selecting a Biology Textbooks?”.
Journal of The American Biology Teacher, 55(1), $14-19$.

Lumpe, A. T dan Beck, J. 1996. A Profile of High School Biology Textbooks Using Scientific Literacy Recommendations". Journal of The American Biology Teacher. 58(3), 147-153.

Nbina, J. B. 2013. The Relative Effectiveness of Guided Discovery and Demonstration Teaching Methods on Achievement of Chemistry Students of Different levels of Scientific Literacy. Journal of Research in Education and Society, 4(1)

Piraksaa C., Srisawasdib N. \& Koulc R. 2014. Effect of Gender on Students' Scientific Reasoning Ability : A Case Study in Thailand. Procedia - Social and Behavioral Sciences, 486 - 491.

Yusuf. S. 2003. Literasi Siswa Indonesia Laporan PISA 2003. Jakarta: Pusat Penilaian Pendidikan. [Online]. Tersedia: http://www.p4tkipa.org. [18 Juni 2008]. 